\title{
SELF-EFFICACY AND ATTRIBUTIONAL STYLE IN GIFTED STUDENTS
}

\author{
Elena Abbate, \& Stefania Pinnelli \\ Department of History, Society and Human Studies, University of Salento (Italy)
}

\begin{abstract}
The contribution, starting from the general construct of self-efficacy, examines the mechanisms of construction of a motivational attributive style, to achieve academic success in gifted students.

The models of interpretation of cognitive giftedness agree in retaining motivation and perseverance as factors determining the success of learning and the transformation of the giftedness into real talent. The perception of self-efficacy and the attributive style guide the motivation and in the persons with high cognitive potential they are not always present. This can lead to a non-directional potential.

What is the function of self-efficacy in promoting talent in students with high cognitive potential? What is the most appropriate type of attributive style to promote in these students? And the role of teachers to enhance motivation, in order to avoid the risk of underachievement and dropout?

The contribution, after having analysed the constructs in the literature proposes an answer to the questions.
\end{abstract}

Keywords: Self-efficacy, motivational attributive style, giftedness, talent.

\section{Introduction}

Self-efficacy is a necessary and central personal resource in human growth. It acts on the cognitive, motivational, affective and decisional processes, determining paths of development, effective adaptation and change.

Every type of behavior during the life span of an individual is configured as intentionality, premeditation and self-regulation. People draw up action plans and strategies to implement them, analyze in advance the possible results of the actions to be taken and activate self-regulation processes to guide behavior. Control and reflection on one's own functioning determines the conviction of personal efficacy which in turn activates different ways of thinking and interpretative schemes: negative and ruinous or positive and "self-enhancing" (Bandura, 2000).

In practice, those who have a low consideration of their abilities in a given domain avoid difficult tasks, show little aspirations, pursue objectives with disengagement, linger on the obstacles they encounter, and finally present a low level of resilience. On the other hand, those who believe in their own active capacities activate functional modalities to the achievement of the objectives, demonstrating interest and involvement in the tasks that they carry out and fix the focus on commitment and perseverance for the achievement of success (Bandura, 1993). These modes of functioning are determined by the profound conviction of being able to produce changes in one's academic, work and social environment, with one's actions. It can be said that the belief in being able to exercise internal and personal control over the situation is fueled by a sense of self-efficacy.

Rotter (1966), elaborating the construct of the locus of control, has differentiated the methods of evaluation of the causes of the results achieved, both positive and negative, in terms of external and internal. Clarifying that people with an external locus of control perceive themselves as powerless, attributing the results obtained to external factors such as luck, chance or circumstances beyond their control. On the contrary, an internal locus of control determines in the subject the conviction of being able to achieve the predetermined results, because these depend directly on one's actions, on one's behavior or on one's own personal characteristic. Rotter's locus of control appears in its bipolarity as a general and stable psychological dimension of attribution, in which not only ideas of impotence or devaluation are understood, but also the sense of security, self-esteem and the ability to face the events of one's life and to manage their changes.

Weiner, subsequently, in an attempt to propose a theory of motivation and emotion based on causal attributions, focuses not only on the perception of internal and external causality, but also on the stable or unstable nature of the cause and its consequent controllability. Three fundamental dimensions derive from this: the stability / instability of the cause, the internal or external locus attributed to it, the controllability / 
uncontrollability on the part of the subject (Weiner, 1985; Pellerey, 2003). The three dimensions of causality influence a variety of positive and negative emotional experiences including gratitude and pride, guilt and shame. These emotions guide and motivate behavior (Weiner, 1985).

The Weiner model, exploring the main causes attributed to success or failure in learning situations, highlights the role of the main causal variables such as the commitment and the skill (internal locus), the ease of the task, the help received or luck (external locus). Each of these causes is distinguished by two characteristics: stability and controllability, so that commitment is an unstable internal cause that can be controlled by the subject; on the contrary, luck is an external, unstable and uncontrollable cause for the individual. People interpret their successes or failures by referring to one or more of these causes, constructing a stable personal scheme that determines one's own attributive style.

There are different styles that are characterized by being more or less functional to the achievement of objectives in the academic or work field. The strategic commitment style $e^{1}$ that attributes success primarily to commitment (understood not only as a physical or cognitive effort, but also as an ability to analyse the task, to select and activate adequate resolving strategies), seems to be the most suitable for achieving good results especially in contexts of school learning. In fact, even in the event of failure, positive expectations of success are maintained. (Ravazzolo et al., 2005).

Different attributive styles, which do not recognize the centrality of commitment and personal agency, are often linked to negative emotional and behavioral experiences. The mistaken belief that failure is due to lacking personal skills can generate a sense of learned helplessness, with a renouncing and passive attitude, accompanied by an experience of inadequacy, resignation, and disengagement, with a tendency to develop performance anxiety and depressive forms (Ravazzolo et al., 2005).

Taking up the research of Collins (1982) and Bouffard-Bouchard, Parent and Larivée (1991), Bandura states that pupils with the same level of cognitive development and knowledge differ in intellectual performance depending on the strength of their self-efficacy convictions. Consequently, the author claims that perceived self-efficacy is a predictor of school successes or failures better than cognitive abilities alone (Bandura, 2000).

Considering what has been said, we will address below how the sense of efficacy develops and is structured in the process of personal growth the sense of efficacy in subjects with high cognitive potential and the role of teachers in this process.

\section{The role of self-efficacy in subjects with high cognitive potential}

The intellectual giftedness is a condition that affects approximately $2 \%$ of the school population (Novello, 2006). In our school system children with high cognitive potential still do not enjoy an official recognition that guarantees specific and shared identification criteria and adequate training paths. Although scientific research has provided valid evidence in arguing that giftedness is a characteristic in potency, an attitude that emerges and develops only in interaction with an inclusive and supportive context (Gagné, 1999), the false myth about having a high potential is in itself a guarantee of success in life is still widespread (Zanetti, 2016). In reality, the gifted student is not always able to recognize and manage his own abilities in the context, risking experiences of suffering and demotivation (Novello, 2016), which manifest themselves in situations of underachievement, dropout and general malaise (Zanetti, 2016). As a potential attitude, talent emerges and is configured as excellence only through the interaction of personal and environmental factors. Gagné talked about these factors in the Differentiated Model of Giving and Talent (DMGT) representing them as the interpersonal and environmental catalysts necessary for the transformation of the gift into talent. Its promotion is a process that due to its importance and complexity cannot be left to the individual, but needs the support and commitment of the whole society (Gagné, 1999, Sorrentino, 2017). Bearing in mind the cognitive and emotional-relational characteristics (Zanetti, 2016; Novello, 2016) and the profiles of a gifted subject as suggested by literature (Betts, Neihart, 1988), the process of promoting talent cannot be separated from considering processes that structure the convictions of effectiveness of a subject. Bandura (2000) also recognizes the interdependence of human agency with the social context, affirming that the conviction of personal efficacy is based not only on personal agency, but also on a type of agency that arises from and in the context and defines collective.

In the exercise of collective agency, people combine their knowledge, skills and resources, form alliance and working together to achieve the goals (Bandura, 2005). This type of agency promotes a sense of collective efficacy that allows the pursuit of higher goals, promotes motivation and stimulates commitment, strengthens resilience in the face of adversity and improves group results. An integrated

${ }^{1}$ On the distinction and the characteristics of the main attributive styles see: Ravazzolo, C., De Beni, R., Moè, A., Stili attributivi motivazionali. Percorsi per migliorare le capacità di apprendimento in bambini dai 4 agli 11 anni. Trento, Erickson, 2005, pp.14-15. 
causation system is generated where socio-structural factors meet individual psychological variables to produce effects on behavior.

An inclusive context is a context that is perceived collectively as effective that creates opportunities and builds paths for the success and well-being of one's own. The school context is recognized as an effectively inclusive community when it activates every resource necessary to support the learning and participation of all students. Searching for these resources both within the school, in its cultures, in its practices, in its teaching and non-teaching staff, in the physical environment, in teaching tools; both outside the school, in families, administrators and in the community. The mobilization of these resources increases the capacity of the school to accept the diversity of each student, so as to recognize and value it equally, designing training courses that take into account the different starting points, interests, experiences and learning styles of each individual student. If these students are people with a high cognitive potential or with different education, living an effective school context becomes an important protection factor against the emergence of behavioral and adaptive problems. If an effective context is first and foremost an inclusive context then it is precisely at school that we must begin to become aware of the potential of gifted children and provide them with adequate paths to foster the thirst for knowledge, support divergent thinking, develop creativity (Zanetti, 2016). The gifted boys need a cognitively stimulating curriculum, which guides them towards interesting goals in order to maintain a high commitment and motivation. They must learn to recognize themselves in their cognitive functioning, to feel able to control processes (internal locus of control), to persevere in commitment when challenges become difficult and to develop resilience in the face of failures, to be, therefore, protagonists of the training course mastering one's talent. In summary, to favor the construction of that profile of gifted more inclined to success that Betts and Neihart (1988) define autonomous learner ${ }^{2}$ and which turns out to be, recalling Weiner, endowed with an attributive strategic commitment style.

A school and family context that favours and supports these processes with a common commitment, must exercise a collective agency, that is a sense of collective self-efficacy based on the conviction that only by combining resources, skills and knowledge can the desired objectives be achieved. Encouraging a sense of self-efficacy and an attributive style functional to educational success helps to avoid the waste of talents, as instead happens in situations of under-performance or early school leaving. In these negative scenarios, the subject passively suffers the will of an environment that does not recognize it, is unable to use its agency, to exercise causal power, is at the mercy of external events over which it has little control (external locus of control) with serious repercussions on motivation and personal performance (Landis, et al. 2013).

\section{Conviction of efficacy and role of teachers}

Overcoming the misconception that the gifted student, for the ow gift possessed, is already predestined for success, implies in the teacher a critical reflection on the role he/she plays in building an effective and inclusive learning context. Above all, it makes it possible to focus attention on the educational and didactic processes and interventions necessary to face special training needs and to question the effectiveness of the methodological tools at its disposal to achieve successful objectives.

The research showed that specific training based on experience and educational practice plays an important protective role for teachers against the influence of stereotypes and false beliefs. "Training strengthens positive attitudes, acts on motivation and a sense of security and self-efficacy, freeing teachers from the fear of failure" (Fiorucci, 2017, p.62).

The student with high cognitive potential is the bearer of a complex formative demand that is configured in the need to engage personally in something meaningful, which gives him a sense of accomplishment and self-efficacy and which guides his efforts towards successful goals. In this perspective the role of teachers is crucial not because it is a dispenser of curricular contents, but because through his convictions, expectations and judgments they influence the convictions of effectiveness of the pupil himself.

Biasi et al. (2014) observed that professors with a high sense of efficacy manage the class competently, they stimulate discussion and support students in difficulty and are a source of gratification for those who experience academic success.

Unlike teachers with low levels of effectiveness are not very supportive and are very critical towards those who fail in the task assigned, are more stressed and not confident in the progress of the class, invest little in the relationship, are demotivating and punitive.

The teacher's sense of effectiveness is strongly linked to enthusiasm, commitment, persistence, has a predictive value on students' learning outcomes, their motivation and their sense of self-efficacy.

${ }^{2}$ For a detailed description of the different types of gifted and talents, see BETTS, G.T., NEIHART, N. (1988), The profile of gifted and talent, Gifted Child Quartery, 32 (2) pp. 248-253. 
(Biasi et al., 2014). "Teachers who are confident in their own training skills create mastery experiences for their students. The uncertainty of their abilities build class environments that tend to undermine self-efficacy and cognitive development". (Bandura, 2005, p. 26).

We can therefore state that the teacher, in constructing a learning context suited to the training needs of pupils with high potential, must surely engage in choosing the most appropriate and functional teaching and educational strategies for educational success. The teacher must also invest resources to promote students an agentive capacity that guides them towards a proactive and generative attitude in all contexts of life. The teacher is also called upon to work on the pupil's perception of abilities, on his expectations of success of the task, on his motivation, and on causal attributions, emphasizing the importance of commitment and perseverance. For the promotion of an attributive style functional to the pupil's academic success, teachers must first know their own attributive style and their convictions of effectiveness.

We have seen how the construct of self-efficacy is important in the life of an individual, because it generates more or less positive beliefs and beliefs that determine its behavior. Even more decisive it becomes for a subject with a higher rating, whose emotional and relational fragility makes him easily a victim of demotivation, incomprehension and isolation, especially in school contexts.

This is why teachers' educational self-efficacy convictions play a fundamental role in building an inclusive learning environment. This in turn must promote a high sense of personal efficacy in young talents, so that they can perceive themselves as creators of their own destiny, managing to live their talent as an opportunity for growth and realization not only for themselves but also for the whole society.

\section{References}

Bandura, A. Self-Efficacy. The Exercise of Control (1997), trans. Autoefficacia. Teoria e applicazioni, Trento Erickson, 2000.

Bandura, A. Adolescent development from an agentic perspective, in Pajares, F., Urdan, T., Self-efficacy and adolescence (2005), trans. Adolescenti e autoefficacia. Il ruolo delle credenze personali nello sviluppo individuale. Trento Erickson, 2012.

Bandura, A. (1993), Perceived Self-Efficacy in Cognitive Development and Functioning, Educational Psychologist, 28(2), pp. 117-148.

Betts, G.T., Neihart, N. (1988), The profile of gifted and talent, Gifted Child Quartery, 32 (2) pp. 248-253.

Biasi, V., Domenici, G., Capobianco, R., Nazarena, P., (2014), Teacher Self-Efficacy Scale (Scala dell'Auto-Efficacia del Docente-SAED): adattamento e validazione in Italia, Journal of Educational, 10, pp.485-509.

Bouffard-Bouchard, T., Parent, S., Larivèe, S., (1991), Influence of self-efficacy on self-regulation and performance among junior and senior high-school age student, International Journal of Behavioral Development, 14, pp.153-164.

Collins J. L.(1982), Self-efficacy and ability in achievement behavior, report presented all'annual meeting of the American Educational Research association, New York

Crepet, P. Le misure del disagio psicologico, Roma, La Nuova Italia Scientifica, 1994.

Fiorucci, A., (2017), I bisogni formativi speciali dei gifted students. Gli atteggiamenti degli Insegnanti, L'integrazione scolastica e sociale, 16, (1), pp. 59-65.

Gagné, F. (1999). Gagné's Differentiated Model of Giftedness and Talent (DMGT). Journal for the Education of the Gifted Vol. 22, Issue 2, pp. $230-234$

Landis, N. R., Reschly A. L. (2013), Reexamining Gifted Underachievement and Dropout Through the Lens of Student Engagement, Journal for the Education of the Gifted, XX(X), pp.1-30.

Novello, A. (2016), Insegnare le lingue a studenti gifted. Strategie didattiche per la plusdotazione, Romanica Cracoviensia, 2, pp. 109-119.

Pellerey, M. (2003), Processi autoregolativi e attribuzioni causali, Orientamenti Pedagogici, 50 (4), pp.651-677.

Ravazzolo, C., De Beni, R., Moè, A., Stili Attributivi Motivazionali. Percorsi per migliorare le capacità di apprendimento in bambini dai 4 agli 11 anni, Trento, Erickson, 2005.

Rotter J. B. (1966), Generalized Expectancies for Internal Versus External Control of reinforcement, Psicological Monographs: General and Applied, 80 (609).

Sorrentino, C., (2017), Giftedness e contesti secondo una prospettiva pedagogica, Italian Journal of Special Education for Inclusion, V (1).

Weiner, B (1985), An Attributional Theory of Achievement Motivation and Emotion, Psychological Review, 92 (4), pp. 548-573

Zanetti, M., A., (2016), Una doppia difficoltà in classe: $i$ bambini ad alto potenziale. Journal of Applied Radical Behavior Analysis. 